\title{
TAR DNA-Binding Protein 43
}

National Cancer Institute

\section{Source}

National Cancer Institute. TAR DNA-Binding Protein 43. NCI Thesaurus. Code C80022.

TAR DNA-binding protein $43(414 \mathrm{aa}, \sim 45 \mathrm{kDa})$ is encoded by the human TARDBP gene.

This protein is involved in the regulation of both transcription and mRNA splicing. 